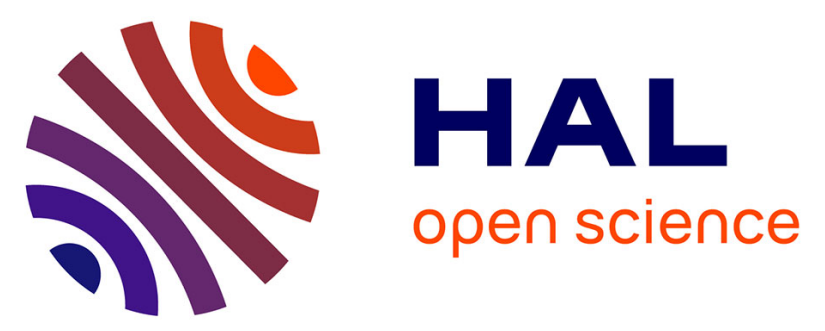

\title{
EvEel (evolutionary ecology based model for eel): a model to explore the role of phenotypic plasticity as an adaptive response of three temperate eels to spatially structured environments
}

Hilaire Drouineau, Christian Rigaud, Françoise Daverat, Patrick Lambert

\section{To cite this version:}

Hilaire Drouineau, Christian Rigaud, Françoise Daverat, Patrick Lambert. EvEel (evolutionary ecology based model for eel): a model to explore the role of phenotypic plasticity as an adaptive response of three temperate eels to spatially structured environments. Canadian Journal of Fisheries and Aquatic Sciences, 2014, 71 (10), pp.1561-1571. 10.1139/cjfas-2014-0090 . hal-01094405

\author{
HAL Id: hal-01094405 \\ https://hal.science/hal-01094405
}

Submitted on 12 Dec 2014

HAL is a multi-disciplinary open access archive for the deposit and dissemination of scientific research documents, whether they are published or not. The documents may come from teaching and research institutions in France or abroad, or from public or private research centers.
L'archive ouverte pluridisciplinaire $\mathbf{H A L}$, est destinée au dépôt et à la diffusion de documents scientifiques de niveau recherche, publiés ou non, émanant des établissements d'enseignement et de recherche français ou étrangers, des laboratoires publics ou privés. 
1 EvEel (Evolutionary ecology based model for Eel): a model to explore the role of phenotypic

2 plasticity as an adaptive response of three temperate eels (Anguilla anguilla, A. japonica and A.

3 rostrata) to spatially structured environments

4

5 Authors:

6

- Hilaire DROUINEAU ( corresponding author)

- affiliations: Irstea, UR EABX Ecosystèmes aquatiques et changements globaux / Pôle Écohydraulique Onema-INP-Irstea

○ tel : +33(0)5 57892709

○ mail: hilaire.drouineau@,irstea.fr Écohydraulique Onema-INP-Irstea

- mail: christian.rigaud@,irstea.fr - mail: francoise.daverat@irstea.fr 
24 Keywords: Anguilla sp., phenotypic plasticity, adaptive response, EvEel, length-at-silvering, sex-

25 determination, habitat use

\section{Abstract}

28 Anguilla anguilla, A. japonica and A. rostrata are three largely distributed catadromous and

29 semelparous species characterized by a long and passive oceanic larval drift between their marine

30 spawning grounds and their nursery areas in continental waters. Their large and spatially

31 heterogeneous environments combined with population panmixia and long and passive larval drift

32 impair the possibility of local adaptation and favour the development of phenotypic plasticity. In

33 this context, we develop EvEel, a model that aims at exploring the role of phenotypic plasticity as

34 an adaptive response of eels. Results suggest that the spatial patterns in terms of sex-ratio, length-at-

35 silvering and habitat use observed at both the distribution area and the river catchment scales may

36 actually be the result of three adaptive mechanisms to maximize individual fitness in spatially

37 structured environments. We think that considering phenotypic plasticity as a paradigm is required

38 to develop appropriate models for this species. 


\section{Introduction}

41 Phenotypic plasticity has been proposed as an adaptive response to environment variability for

42 many species (Levins 1963; Gotthard and Nylin 1995; Pigliucci 2005). It has been demonstrated

43 that in some cases, fitness gains arise from plastic phenotypes compared to non-plastic ones and that

44 consequently, phenotypic plasticity may be selected by natural selection (Schlichting 1986; Sultan

45 1987; Travis 1994). Moreover, Ernande and Dieckmann (2004) demonstrated that density-

46 dependence favours the selection of plastic phenotypes. The phenotypic plasticity issue is all the

47 more interesting for temperate eels (European eel Anguilla anguilla, American eel A. rostrata and

48 Japanese eel A. japonica) that meet all the conditions favouring the emergence of phenotypic

49 plasticity while impairing the possibility of local adaptation: panmictic populations with large

50 distribution areas and density-dependent population dynamics, concomitantly with a large

51 variability in life history traits, life tactics and demographic attributes.

52 Temperate eels are three semelparous catadromous species displaying remarkable similarities in

53 their life history traits (Daverat et al. 2006; Edeline 2007). All three species have a large distribution

54 area, from Morocco to Norway (Tesch 2003) for the European eel, from $\sim 7^{\circ} \mathrm{N}$ to $\sim 55^{\circ} \mathrm{N}$ for $A$.

55 rostrata (Helfman et al. 1987; Edeline 2007) and from Northern Philippines to Korea for $A$.

56 japonica. The populations are considered as panmictic since no clear genetic difference at neutral

57 loci was observed along the distribution area (Han et al. 2010; Als et al. 2011; Pujolar 2013). All

58 three species are characterised by a long and passive larval drift (larvae are called leptocephali)

59 between spawning grounds (Sargasso Sea for A. anguilla and A. rostrata (Schmidt 1923; McCleave

60 1993), and west of the Mariana Islands for A. japonica (Tsukamoto 1992)) and continental nursery.

61 Leptocephali metamorphose into glass eels when arriving on the continental shelf (Tesch 2003).

62 Then, glass-eels colonise continental waters where they become pigmented yellow eels and remain

63 during their growth phase that lasts several years. After a variable period generally lasting from 3 to

6415 years, yellow eels metamorphose again into silver eels. They achieve their sexual maturation 
while migrating back to spawning grounds.

66 As leptocephali drift passively to the continental shelf (McCleave 1993; Kettle and Haines 2006;

67 Bonhommeau et al. 2009), larvae are not able to select the river catchment in which they will grow.

68 Consequently, eels are distributed in contrasted environments (from Mauritania to Norway for example for European eel, or from Northern South-America to Greenland for the American eel), and more specifically with contrasting temperature which is a primary driver of physiological

71 processes, affecting both growth and survival (Brown et al. 2004).

72 Concomitantly with this environmental heterogeneity, a large phenotypic diversity is observed at the

73 distribution area and at the river catchment scales. For example, sex-ratio is spatially highly

74 heterogeneous at the distribution area and at the river catchment scale (Vladykov 1966; Helfman et al. 1987; Oliveira et al. 2001). Vladykov (1966) and Helfman et al. (1987) mentioned a female biased sex-ratio in the northern part of the distribution area. Krueger \& Oliveria (1999) and Oliveira et al. (2001) argued that sex-ratio variability can also vary a lot within a limited range of latitudes under the influence of local conditions. A large data collection of existing observations carried out by Kettle et al. (2011) for both A. rostrata and anguilla confirms this latitudinal pattern. Sexdetermination for eel is still poorly known but is controlled by environmental factors (Geffroy

81 2012). Environmentally controlled sex-determination is generally selected by evolution when the

82 environmental factor differentially affects the fitness of males and females (Mayhew 2006).

83 Environmental sex-determination is not rare for fishes, temperature being the main driving factor,

84 though the influence of density or social interactions have also been observed for some species

85 (Devlin and Nagahama 2002). Several factors have been proposed as driving factors for eel sex-

86 determination. Regarding eel density, a male biased sex-ratio is generally observed when eel density

87 is high (Roncarati et al. 1997; Tesch 2003; Han and Tzeng 2006). This has been observed at the

88 catchment scale where males are concentrated in the downstream part of the catchment (Oliveira

89 and Mccleave 2000; Tesch 2003), though this observation may result from a more limited

90 colonisation ability of males. More convincing observations come from catchments where 
91 modifications of densities have resulted in modifications of the sex-ratio (Poole et al. 1990;

92 Roncarati et al. 1997; Tesch 2003), and by observations in controlled environment experiments

93 (Colombo and Grandi 1996; Beullens et al. 1997; Holmgren et al. 1997). Growth rate in youngest

94 stages is also suspected to play a role in sex-determination, however results are less obvious.

95 Holmgren (1996) and Holmgren and Mosegaard (1996) observed in controlled experiments that fast

96 growing (especially in weight) young eelspreferentially turn into males. However results were

97 unclear because of concomitant variation in density. More generally, Geffroy (2012) assumed that

98 the global quality of the environment may be the main factor affecting sex-determination.

99 This issue of sex-determination is of major importance because males and females are supposed to

100 display distinct life tactics (Helfman et al. 1987). The reproduction success of a male does not vary

101 with its body size, consequently males are assumed to follow a time-minimising strategy, leaving

102 continental waters as soon as they have enough energy to migrate to the spawning grounds

103 (Vollestad 1992). This assumption would explain why male silver eels display rather similar

104 weights and sizes (Oliveira 1999)all over the distribution area (Vollestad 1992; Oliveira 1999). Such

105 a size threshold may correspond to the size at which energy stores are sufficient to undergo the

106 transoceanic reproduction migration (Van Den Thillart et al. 2007). By contrast, fecundity and

107 consequently reproduction success of females is mainly influenced by body size. Consequently,

108 females are assumed to follow a size-maximising strategy, adapting their length-at-silvering to local

109 growth and mortality conditions in order to find a trade-off between survival and fecundity.

110 Latitudinal pattern of female silver eel length is often mentioned with larger females in the northern

111 part of the distribution area (slow growth but lower mortality) than in the southern part (Helfman et

112 al. 1987; Davey and Jellyman 2005; Jessop 2010).

113 In addition to sex-ratio and length-at-silvering variability, eels also display a large range of tactics in

114 terms of growth and habitat use, some settling in estuarine waters while others move far upstream in

115 river catchments (Tsukamoto et al. 1998; Daverat et al. 2006; Arai and Chino 2012). Growth rate in

116 salted and brackish downstream parts of catchments is significantly higher than in upper parts of the 
117 catchments (Helfman et al. 1984; Melià et al. 2006b; Daverat et al. 2012). A lower mortality in

118 upper parts of river catchments is sometimes assumed to balance the associated lower growth.

119 Consequently, upstream habitats with more limited intraspecific competition may still be favourable

120 especially for females which can adapt their length-at-silvering to balance lower growth rates.

121 Edeline (2007), for example, assumed that catchment colonisation and tactics in habitat use by eels

122 correspond to a conditional evolutionary stable strategy (Gardner et al. 1987). A conditional

123 evolution stable strategy is a generalisation of evolutionary stable strategy in which an individual

124 can express different phenotypes (the tactics of the conditional strategy) depending on its

125 environmental, social and physiological status (cueing trait). According to Edeline (2007),

126 individuals with high energetic status would migrate upstream to avoid competition and then settle

127 (i.e. change tactics) when their energetic status becomes too low or when the benefits do not

128 outweigh the costs of migration. This assumption is challenged by Cairns et al. (2009) who did not

129 observe mortality differences large enough to balance variations in growth between different

130 habitats. Cairns et al. (2009) concludes that the decrease of natural mortality (competition) would

131 not outweigh the cost of migration and the decrease in growth rate.

132 As a summary, eels display a large phenotypic and tactical variability at both the distribution area

133 and the catchment scales including sex-determination, females length-at-silvering and use of growth

134 habitats within a catchment with higher density downstream. Since eels meet all conditions

135 favouring phenotypic plasticity, the objective of this paper is to explore if those spatial patterns may

136 result from adaptive responses to spatially structured environments and density-dependence, or if

137 they are a "passive" response to environmental variability (Van Kleunen and Fischer 2005). This

138 analysis is carried out using EvEel (Evolutionary ecology model for Eel): a model exploring the

139 role of phenotypic plasticity as an adaptive response of eels to spatially structured environments. 


\section{Material and methods}

\section{Model rationales and definition of the spatial patterns}

142 The model is based on the assumption that the growth phase of eels in continental waters starts by

143 two successive events, sex-determination and growth habitat selection, which are two adaptive

144 responses to environmental variability. Consequently sex-determination and growth habitat

145 selection are assumed to be two "decisions that maximise expected fitness". Assuming that

146 decisions are made to maximise expected fitness is the main assumption when modelling adaptive

147 life history decisions (Mangel and Clark 1988). For example, in the optimal foraging theory,

148 animals are assumed to move to maximise their food intake which is considered as a proxy of their

149 fitness (Mangel and Clark 1986; Giske et al. 1998; Railsback and Harvey 2013). Similarly, models

150 based on the life history theory posits that the schedule and duration of life traits are the results of

151 natural selection to optimize individual fitness (Giske et al. 1998). For example, McLaren (1963)

152 developed a model of spatial distribution of zooplankton based on habitat profitability, by modelling

153 the effect of water temperature on reproduction rate.(2013) Life-history theory models generally

154 focus on finding an optimal trade-off between age at maturity, fecundity and survival (McNamara

155 and Houston 1992; Clarke 1993; Giske et al. 1998). Alternative migratory tactics of salmonids

156 (anadromous, jacks and freshwater resident) may be interpreted as an adaptation to local

157 environment in the context of life-history theory (Dodson et al. 2013).

158 Assumed that males adopt a time-minimising strategy, their fitness may be approximated by the

159 probability to survive until length-at-silvering. On the other hand, females are assuming to adopt a

160 size-maximising strategy, seeking an optimal trade-off between length-at-silvering (fecundity) and

161 survival, consequently females fitness can be approximated by the product of expected fecundity at

162 the length-at-silvering multiplied by the probability to survive until this length.

163 Following Grimm and Railsback (2012), we applied a pattern-oriented modelling approach by

164 comparing model outputs to the following observed and documented spatial patterns: 
- at the distribution area scale:

1. male-biased sex ratio in the southern part of the distribution area and female-biased

- at the river catchment scale:

4. higher density downstream than upstream

\section{Distribution area scale: sex-determination and length-at-silvering as adaptive} mechanisms to a wide variety of spatially structured environmental conditions

182 We assume that female fitness may be approximated by the product of the expected number of eggs 183 at length-at-silvering and the probability to survive until this length-at-silvering $L s_{f}(r)$, i.e. the mean 184 expected number of eggs produced by each female. Following De Leo and Gatto (1995), we assume

185 that growth is well represented by a Von Bertalanffy growth model: $L(t, r)=L_{\infty} \cdot\left(1-e^{-K(r)\left(t-t_{0}\right)}\right)$ 
coefficient.

188 Consequently, age-at-silvering $A s_{f}(r)$ is:

189
1) $A s_{f}(r)=-\frac{1}{K(r)} \cdot \log \left(\frac{L_{\infty}-L s_{f}(r)}{L_{\infty}}\right)+t_{0}$

190 If we denote $L_{g}$ the length at recruitment which is supposed to happen at $t=0$, we get:

191

2) $t_{0}=\frac{1}{K(r)} \cdot \log \left(\frac{L_{\infty}-L_{g}}{L_{\infty}}\right)$

192 and consequently:

193
3) $A s_{f}(r)=\frac{1}{K(r)} \cdot \log \left(\frac{L_{\infty}-L_{g}}{L_{\infty}-L s_{f}(r)}\right)$

194 Von Bertalanffy parameters $K(r)$ and $L_{\infty}$ are generally largely correlated (Pilling et al. 2002;

195 Siegfried and Sansó 2006; Eveson et al. 2007). Regarding eels, Melià et al. (2006a) found a strong

196 linear correlation between the two parameters estimates. Consequently following de Pontual et al.

197 (2006) and Drouineau et al. $(2010,2012)$ we assume that $L_{\infty}$ is fixed and that only $K(r)$ varies.

198 This assumption is also consistent with the Dynamic Energy Budget theory in which $L_{\infty}$ is not

199 affected by temperature variations (Kooijman 2000).

201 From equation 3, we can calculate the proportion of individuals that survive till length-at-silvering

203

$$
\text { 4) } p_{f}(r)=e^{-M(r) \cdot A s_{f}}(r)=\left(\frac{L_{\infty}-L_{g}}{L_{\infty}-L s_{f}(r)}\right)^{\frac{-M(r)}{K(r)}}
$$

204 and the reproductive output of females which we consider as a proxy of the female fitness $\pi_{f}(r)$ is

$$
5)_{\pi_{f}}(r)=\left(a_{1}+a \cdot L s_{f}(r)^{b}\right) \cdot\left(\frac{L_{\infty}-L_{g}}{L_{\infty}-L s_{f}(r)}\right)^{\frac{-M(r)}{K(r)}}
$$


206 with $a_{l}, a$ and $b$ parameters from a fecundity-at-length relationship proposed by Andrello et al.

207 (2011), in which fecundity is assumed to be a linear function of weight, the latter scaling

208 allometrically to length (Melià et al. 2006a).

209 As previously mentioned, females length-at-silvering is assumed to be a trade-off between

210 fecundity and survival probability, consequently we numerically estimated $L s_{f}(r)$ as the value that

211 maximises $\pi_{f}(r)$ in the growth and survival conditions of $r$. This trade-off between fecundity is

212 illustrated by Fig. 1.

214 Conversely, male reproduction success is assumed to adopt a time minimising strategy, leaving

215 continental waters as soon as they have reached the minimal length to undergo the reproduction

216 migration (Helfman et al. 1987; Vollestad 1992). Consequently, we assume that male length-at-

217 silvering is constant (as observed by Oliveira (1999)) and corresponds to the minimal length to

218 carry out the migration to the spawning grounds. Males fitness $\pi_{m}(r)$ may thus be approximated by

219 the probability to survive until length-at-silvering:

220

6) $\pi_{m}(r)=\left(\frac{L_{\infty}-L_{g}}{L_{\infty}-L s_{m}(r)}\right)^{\frac{-M(r)}{K(r)}}$

222 The ratio $\pi_{f}(r) / \pi_{m}(r)$ is then calculated for different values of $K(r)$ and $M(r)$ varying from 0 to 0.3

223 year ${ }^{-1}$. For each case, the optimal female length-at-silvering $L s_{f}(r)$ is also estimated. This produces

224 a diagram of ratio of fitness. A large ratio indicates a marginal fitness gain for females while a

225 smaller ratio indicates a marginal fitness gain for males. This also produces a diagram of females

226 length-at-silvering, as a function of $K(r)$ and $M(r)$. We do not consider any feedback in sex-

227 determination: the expected fitness of choosing male or female does not depend on how many other

228 eels choose which sex. 
230 Natural mortality and growth rates of living organisms are largely influenced by temperature

231 because of physiological processes (Brown et al. 2004). Correlation between eel natural mortality

232 (Bevacqua et al. 2011b), growth (Daverat et al. 2012) and temperature has been observed.

233 Consequently, all combinations of values of $M(r)$ and $K(r)$ are not physiologically possible. Pauly

234 (1980) has carried out a large meta-analysis linking growth parameters to survival for numerous

235 marine fish species:

236

7) $\log (M(r))=-0.0066-0.279 \cdot \log \left(L_{\infty}\right)+0.6543 \cdot \log (K(r))+0.4634 \cdot \log (T(r))$

238 We use this relationship with temperatures ranging from $5^{\circ} \mathrm{C}$ to $25^{\circ} \mathrm{C}$, and plot this relation on the 239 diagrams of ratio of fitness and females length-at-silvering as functions of $K(r)$ and $M(r)$, to detect 240 plausible combinations of growth and mortality rates. We also plot hypothetical points of growth 241 and mortality to illustrate how sex-ratio and length-at-silvering may vary between Scandinavia, Bay

242 of Biscay and Mediterranean area: Scandinavia is characterised by a low temperature (we chose $5^{\circ} \mathrm{C}$ 243 as an illustration) and a slow growth (see (Helfman et al. 1987; Jessop 2010) for description of

244 latitudinal pattern in growth). Mortality rate was then estimated using equation 7, Conversely,

245 Mediterranean area is characterised by a warmer temperature (we chose $25^{\circ} \mathrm{C}$ as an illustration) and 246 a faster growth.

248 Parameters values are presented in the control experiment scenario in table 1. 
253

254

255

256 The river catchment is represented by $n$ contiguous cells, the first cell representing the river mouth

257

258

259

260

261

262

10) $M(r, i)=M(r, n)+(M(r, 1)-M(r, n)) \cdot$ cauchit $\left(\frac{i}{n}, \gamma_{M}\right)$

271 We denote $M_{m}(r, i)$ and $M_{f}(r, i)$ the instantaneous natural mortality rates for males and females.

272 For simplicity, following Lockwood (1980), we assume that natural mortality increases linearly

273 with density (Hixon and Jones 2005)though logarithmic relationship may also been assumed (Myers

274 and Cadigan 1993; Fromentin et al. 2001) and provide similar results: 
11) $M_{m}(r, i)=M(r, i)+\left(N_{m}(r, i)+N_{f}(r, i)\right) \cdot \alpha_{m}$

276

12) $M_{f}(r, i)=M(r, i)+\left(N_{m}(r, i)+N_{f}(r, i)\right) \cdot \alpha_{f}$

277 with $N_{m}(r, i)$ and $N_{f}(r, i)$ the number of males and females in cell $i$ while $\alpha_{m}$ and $\alpha_{f}$ are two

278 parameters that control the intensity of density-dependence.

280 In each cell $i$, males and females fitnesses (denoted $\pi_{m}(r, i)$ and $\pi_{f}(r, i)$ ) are calculated using

281 equations 5 and 6 and assuming a density-dependent natural mortality (Vollestad and Jonsson 1988;

282 De Leo and Gatto 1996; Lobón-Cerviá and Iglesias 2008; Bevacqua et al. 2011b) as described in equations 11 and 12 :

284

$13)_{\pi_{f}(r, i)}=\left(a_{1}+a \cdot L s_{f}(r, i)^{b}\right) \cdot\left(\frac{L_{\infty}-L_{g}}{L_{\infty}-L s_{f}(r)}\right)^{\frac{-M_{f}(r, i)}{K(r, i)}}$

285

14) $\pi_{m}(r, i)=\left(\frac{L_{\infty}-L_{g}}{L_{\infty}-L s_{m}}\right)^{\frac{-M_{m}(r, i)}{K(r, i)}}$

$L s_{f}(r, i)$ is estimated as the length maximising $\pi_{f}(r, i)$ (see Fig .1).

For each cell $i$, we estimate the mean length-at-silvering as:

288

15) $\overline{L_{s}(r, i)}=\frac{N_{m}(r, i) \cdot L s_{m} \cdot \pi_{m}(r, i)+N_{f}(r, i) \cdot L s_{f}(r, i) \cdot \frac{\pi_{f}(r, i)}{a_{1}+a \cdot L s_{f}(r, i)^{b}}}{N_{f}(r, i) \cdot \frac{\pi_{f}(r, i)}{a_{1}+a \cdot L s_{f}(r, i)^{b}}+N_{m}(r, i) \cdot \pi_{m}(r, i)}$

289 and standardised fitnesses along the riverside as:

16) $\pi_{m, s a d}(r, i)=\frac{\pi_{m}(r, i)}{\max _{j}\left(\pi_{m}(r, j)\right)}$

17) $\pi_{f s t a d}(r, i)=\frac{\pi_{f}(r, i)}{\max \left(\pi_{f}(r, j)\right)}$ 
293 We assume that the $N_{m}$ males and the $N_{f}$ females settle in the cell of maximum fitness. Based on this

294 assumption, males and females are distributed in the river catchment by applying the following

295 algorithm:

- $\quad$ For $k$ from 1 to $\max \left(N_{m}, N_{f}\right)$

i.e. males and females are put one after the other in the cell of maximum fitness.

302 The procedure is repeated with four different sets of model parameters. Figure 2 summarizes the and a small gradient in the fourth one.

For each set, we analyse different outputs: $N_{f}(r, i), N_{m}(r, i), \pi_{f}(r, i), \pi_{m}(r, i), L s_{f}(r, i), M_{f}(r, i)$ and $M_{m}(r, i)$.

\section{Results}

Distribution area scale: sex-determination and length-at-silvering as adaptive

314 The ratio of fitness for various conditions of $K(x)$ and $M(x)$ (Fig. 3) demonstrates that high mortality 
315 tends to favour males as compared to females fitness. If we assume that high density increases

316 mortality because of intra-specific competition, this may explain why males-biased sex-ratios are

317 observed in high density environments.

318 Fast growth rate seems to favour females with respect to males. This is not consistent with the

319 observed pattern of sex-ratio at the distribution area, with female biased sex-ratio in the northern

320 part (slow growth) and male biased sex-ratio in the south (fast growth). However, the physiological

321 relationship (Pauly 1980) between $M(r)$ and $K(r)$ implies that in the southern part (white circle -

322 Fig. 3) fast growth is generally associated with higher natural morality, and consequently males

323 become favoured with respect to females compared to Northern area (black circle - Fig. 3), which is

324 consistent with observations.

325 Consequently, at the distribution area, the model mimics the geographical pattern of sex-ratio and is

326 consistent with male-biased sex-ratios in high density environment.

327 Looking at length-at-silvering as a function of $M(r)$ and $K(r)$ (Fig. 4), we observe that the model

328 predicts largest females in cold conditions (black circle) than in warm conditions (white circle).

329 This is consistent with the observation of largest silver eels females in the northern part of the

330 distribution than in the southern part (Fig. 4).

331 As a summary, the model mimics all three spatial patterns observed at the distribution area scale 332 (Table 2).

River catchment scale: habitat selection, sex-ratio and length-at-silvering as adaptive mechanisms within a catchment

336 Without density-dependence (set S0 - Fig. 5), all males and females concentrate downstream the

337 river. In this situation, dispersion in the catchment would not correspond to a conditional

338 evolutionary stable strategy, as suggested by Cairns et al. (2009). 
339 If we consider that natural mortality is partly density-dependent (set S1 - Fig. 5), males and females

340 are distributed all along the river, with highest densities downstream the catchment. However, males

341 and females have exactly the same distribution while only females are observed upstream in the

342 field. Relative fitness and length-at-silvering is constant all along the river in this situation.

343 If we assume lower mortality rate upstream than downstream (set S3 - Fig. 5), results are not

344 changed drastically and males and females spatial distributions are still similar.

345 Consequently, dispersion may be a conditional evolutionary stable strategy if we assume that part of

346 the natural mortality is density-dependent. However, it does not explain why the spatial

347 distributions of males and females are different.

348 With set S2 (Fig. 5), we assume that males are less sensitive than females to density-dependence.

349 Set S2 produces results rather similar to field observations. First, males are concentrated in the

350 downstream part of the catchment, where growth is faster, while females are distributed more

351 upstream in zone with lower fish density. When looking at length-at-silvering, silver eels are

352 smaller downstream (where there are more males) than upstream. Moreover, natural mortality is

353 rather constant downstream (where males are concentrated), which may explain why Cairns et al.

354 (2009) do not observe high variations in natural mortality.

355 To conclude, density-dependence is required to mimic catchment colonisation (Table 2) and all the

356 patterns are mimicked if we assume that males are less sensitive than females to density-

357 dependence.

\section{Discussion}

360 The aim of this paper was to explore if few assumptions based on evolutionary concepts may explain the spatial patterns observed in the 3 temperate eels in term of sex-ratio, length-at-silvering and habitat distribution, both at the distribution area scale and at the river catchment scale. Six spatial patterns were listed and the model mimics all of them at both distribution area and river 
catchment scales (Table 2). This does not demonstrate that our assumptions are correct, however, it

365

suggests that sex-determination, length-at-silvering and growth habitat selection may be interpreted as adaptive plasticity selected by evolution to respond to the highly variable and spatially structured environmental conditions encountered by temperate eels. An extension to tropical eels would be interesting in the future.

Interestingly, Côté et al. (2009, 2014) and Gagnaire et al. (2012) have recently explored an alternative hypothesis. Côté et al. (2009) observed permanent growth rate differences between eels originating from two different regions that were reared in similar conditions. Gagnaire et al. (2012) observed genetic differences between eels originating from different sites. They assumed that despite population panmixia, local conditions may select adaptive alleles that are then reshuffled again during the next reproduction. The two hypotheses are not totally contradictory: the two mechanisms, i.e. phenotypic plasticity and genetic adaptation, may complement each other as adaptive responses. In the future, it would be interested to turn EvEel into a demo-genetic model (Piou and Prévost 2012) or to a quantitative genetic model that incorporates phenotype plasticity similar to the model developed by Baskett et al. (2005). In this model, each individual is characterised by its genotype which corresponds to the genetic predisposition to mature at a given size (that would be length-at silvering for eel). However, the phenotype is assumed to be a balance between the genotype and a response to environment through phenotypic plasticity.

Within a river catchment, Edeline (2007) proposed that colonisation may correspond to a conditional evolutionary stable strategy, assuming that lower growth rates upstream were compensated by lower mortality rates. This point of view was challenged by Cairns et al. (2009) who did not observe large variations of natural mortality rates in the field. However, our model suggests that, despite these limited variations of natural mortality, the colonisation and the choice of a growth habitat may still correspond to fitness maximisation strategy. If we assume that females are more sensitive to density-dependent mortality than males, males are concentrated downstream 
where Cairns et al. (2009) made their observations, a zone where the model predicts that their natural mortality rate is rather constant (Fig. 5, scenario S2). It is well known than densitydependence plays a major role in eel dynamics (De Leo and Gatto 1996), especially in migratory behaviour (Geffroy and Bardonnet 2012). Our assumption of distinct density-dependent sensitivity between males and females, i.e. females suffering a higher density-dependant natural mortality rate than males, is plausible for two main reasons: First, Holmgren et al. (1997) observed that males in young stages have a faster growth in weight, with higher condition indices, and so they may become dominant with respect to females. Secondly, we may assume that males may have evolved to be more adapted to high-density since males biased sex-ratios are observed in high density environments. Gender difference in sensitivity to intraspecific competition has already been observed for insects (Gibbs et al. 2004; Tsurim et al. 2013) and birds (Clobert et al. 1988). For example, Gibbs et al. (2004) demonstrated in controlled experiments that females of a butterfly were more adversely affected by high density than males. In the model, we assumed that densitydependence affects natural mortality because of negative effects of intra-cohort and inter- cohort densities on mortality have been observed in many studies (Vollestad and Jonsson 1988; De Leo and Gatto 1996; Lobón-Cerviá and Iglesias 2008; Bevacqua et al. 2011a, 2011b).

In our model, we assume that only natural mortality was impacted by density-dependent processes though intra-specific competition may also result in lower growth rates in reality. However, since fitness is approximated by a function of the ratio of instantaneous natural mortality over Brody growth coefficient in our model (see equations 5 and 6), the results would not change if modelling a density-dependant growth rate.

411 EvEel is based on few evolutionary assumptions: (i) sex-determination is an adaptive response to 412 favour sex with highest fitness in a given environment (assumption consistent with what is observed 413 on many species having an environmental sex-determination (Mayhew 2006)), (ii) since females 414 adopt an size-maximising strategy, fitness may be approximated by the product of fecundity and 415 survival rate, (iii) since males adopt a time-minimising strategy, their fitness may be approximated 
416 by their survival rate, (iv) females are more sensitive to intra-specific competition than males and

417 (v) colonisation and growth habitat selection in a catchment is based on the maximisation of the

418 fitness. Only five assumptions are enough to mimic the main spatial pattern of sex-ratios, length-at-

419 silvering and distribution at the distribution area scale and at the river catchment scale. However,

420 mimicking patterns does not validate (or invalidate) those assumptions and controlled experiments

421 would be required to investigate their reliability.

422 Sex-determination, length-at-silvering and habitat selection are not conscious choices of eels.

423 Optimality models assumes that decisions are made to maximize expected future fitness though

424 organisms do not understand the world they live in and are not able to predict the future. However,

425 evolution has selected animals that undertake those types of decisions in given environmental

426 conditions (Giske et al. 1998). Eel plasticity may be influenced by a few environmental factors so

427 that eels may adapt to the wide range of environmental conditions they may encounter. Among

428 these factors, temperature probably plays a major role by affecting growth and mortality rates. Food

429 availability also plays a role through natural mortality and density-dependence. More generally,

430 global environment quality would affect those three mechanisms, as proposed by Geffroy (2012) for

431 sex-determination.

432 Temperature is known to affect most physiological processes (Brown et al. 2004; Clarke 2006).

433 Pauly (1980) proposed a relation between somatic growth, natural mortality and temperature. This

434 relation was fitted mainly at the inter-specific level, however we considered that this relationship

435 was still relevant at the intra-specific level for two reasons. First in the database analysed by Pauly

436 (1980), many species were included more than once (Gadhus morhu was considered 8 times for

437 example) with growth and mortality estimates from distinct regions. This tends to demonstrate that

438 the relationship remains correct at the intra-level scale. Secondly, the arguments suggested by Pauly,

439 i.e. increased physiological mortality and increased predation, to explain a direct relationship are

440 still valid at the specific level. Indeed, high temperature increases all metabolic rates (Clarke and

441 Johnston 1999; Clarke 2003) leading to higher growth rates (Brown et al. 2004). However, resting 
442 metabolic rates (and consequently the energy required for maintenance) (Clarke 2003) and inter-

443 specific interactions (competition, predation...) (Brown et al. 2004) also increase with temperature,

444 potentially leading to higher natural mortality rates.

445 Pauly's equation (1980) describes a general trend in growth and mortality with temperature which is

446 considered correlated to latitude in our study. However, this general trend may be altered by local

447 conditions. Upwellings for example may disrupt (i) the temperature/latitude gradient and (ii) the

448 growth rate/temperature relationship because of high productivity. Specific habitats, such as lakes,

449 may also disrupt the trend and may explain the phenotypic variability observed by Krueger and

450 Oliveira (1999) and Oliveira et al. (2001) at similar latitudes.

451 Provided our assumptions are valid, it is interesting to analyse the effect of various sources of

452 anthropogenic mortalities. Glass-eels fisheries downstream river catchments tend to decrease eel

453 densities which may lead to a change in sex-ratio towards females and to a decrease of the

454 colonisation of upstream habitats. Remaining individuals are consequently located in downstream

455 habitats where growth is faster mitigating the impact of the fishery. An obstacle to upstream

456 colonisation implies higher densities of individuals downstream. An obstacle close to the mouth

457 would result in a change of sex-ratio towards males (impacting undetermined young eels) or block

458 females which are very sensitive to density-dependence.

459 This first version of EvEel is simple. It does not model population dynamics and assume that fishes

460 are omniscient (perfect knowledge of the entire river catchment) and omnipotent (they are able to

461 migrate to any part of the catchment without any delay). Moreover, it assumes that sex-

462 determination and choice of growth habitat are two successive events that occur very early in the

463 growth phase in continental waters. The reality is more complex: sex-determination occurs between

$46420 \mathrm{~cm}$ and $30 \mathrm{~cm}$ and consequently, colonisation has already started. Moreover, it has been

465 demonstrated that some eels that settle upstream can then move downstream to more favourable

466 habitats when density decreases (Daverat et al. 2006). The model simplicity explains the rough

467 contrasts in the spatial distribution of individuals within a catchment and in the distribution of 
468 length-at-silvering. It would be interesting in the future to incorporate population dynamics and to

469 apply the model to a real river catchment. Basin model proposed by MacCall (1990) and diffusion-

470 advection models (Mullen 1989; Bertignac et al. 1998) would be relevant solution to model eel

471 spatial distribution. Diffusion-advection model would allow to incorporate dynamics in EvEel.

472 These types of models are all based on theoretical ecological concepts (fitness) which are often

473 interesting to explore assumptions that may be validated in the future (Willis 2011). These models

474 would probably result in smoother transitions between males and females and in length-at-silvering

475 because of diffusion. It would be very interesting to compare the results of those models to the

476 outputs of mechanistic or statistical models that have been used to model eels spatial distribution

477 (Ibbotson et al. 2002; Lambert et al. 2011; Jouanin et al. 2012).

478 In the current version of the model, we only consider the growth phase in continental waters and we

479 do not consider the larval drift and the spawning migration. Depending on the river catchment,

480 distance to spawning grounds and consequently migration duration may vary. Larval drift being

481 passive, there is probably no systematic inter-individual difference in fitness. Glass-eels may recruit

482 with variable lengths and energetic resources at different latitudes, however our results were not

483 affected when varying $L g$. Regarding spawning migration, Clevestam et al. (2011) suggested that

484 silver eels from the Baltic Sea, one of the most distant region from A. anguilla spawning grounds,

485 may be too small to undergo the migration. Consequently, it would be interesting to take into

486 account this migration in a future version of the model.

487 Regarding length-at-silvering, the model produces smaller silver eels downstream where males are

488 dominant than upstream where females are dominant. This pattern is consistent with observations.

489 Regarding females length-at-silvering, it is constant over the whole catchment. Possible gradient of

490 female length-at-silvering is sometimes suspected in the literature though evidence is small. By

491 taking into account population dynamics, and especially migration dynamics, in the model, fast

492 migrating females would benefit from upstream habitat with lower density since all females would

493 not be able to reach upstream habitat, resulting in females with slightly larger length-at-silvering. 
494 To conclude, the study of phenotypic plasticity has progressed significantly over the past few

495 decades (Pigliucci 2005) and empirical evidences have been accumulated for many taxa (Ernande

496 and Dieckmann 2004). Regarding diadromous fishes, the role of phenotypic plasticity in explaining

497 some geographic gradients in migratory behaviour of salmonids have for example been underlined

498 by Dodson et al (2013). We think that temperate eels are relevant species to work on phenotypic

499 plasticity. Their large distribution area with spatially structured environments, panmixia and passive

500 larval drift limit the possibility of local adaptation and favours phenotypic plasticity as an adaptive

501 response. Phenotypic plasticity in terms of sexual-determination and subsequent sex-ratio (Davey

502 and Jellyman 2005), length-at-silvering (Vollestad 1992), growth rate (Geffroy and Bardonnet

503 2012), natural mortality rate and migration behaviour (Edeline 2007; Cairns et al. 2009) have

504 actually been documented and analysed for a long time. However, they have generally been

505 considered separately, or two by two, without considering the entire continental life cycle of eels.

506 To our knowledge, it is the first time that all those mechanisms are analysed simultaneously in a

507 single model that considers the implications of life history traits and tactical choices as adaptive

508 responses to highly variable environmental conditions. More generally, we think that evolutionary

509 ecology may provide valuable insights to better understand the continental phase of this species.

510 Phenotypic plasticity has been considered as a nuisance parameter in evolutionary study before

511 becoming a paradigm (Pigliucci 2005). Phenotypic variability is also considered as a nuisance

512 (noise) in population dynamic models for eels. We are alike convinced that phenotypic plasticity

513 should become a paradigm to develop appropriate models for this species.

\section{Acknowledgements}

516 We would like to thank Guy Verreault and Martin Castonguay for the fruitful discussions we had

517 about this paper. We also would like to thank to anonymous referees who helped to improve the

518 quality and the clarity of this manuscript. 


\section{References}

521

Als, T.D., Hansen, M.M., Maes, G.E., Castonguay, M., Riemann, L., Aarestrup, K., Munk, P., Sparholt, H., Hanel, R., and Bernatchez, L. 2011. All roads lead to home: panmixia of European eel in the Sargasso Sea. Mol Ecol 20: 1333-1346.

Andrello, M., Bevacqua, D., Maes, G.E., and De Leo, G.A. 2011. An integrated geneticdemographic model to unravel the origin of genetic structure in European eel (Anguilla anguilla L.). Evol. Appl. 4: 517-533.

Arai, T., and Chino, N. 2012. Diverse migration strategy between freshwater and seawater habitats in the freshwater eel genus Anguilla. J. FISH Biol. 81: 442-455.

Baskett, M.L., Levin, S.A., Gaines, S.D., and Dushoff, J. 2005. Marine reserve design and the evolution of size at maturation in harvested fish. Ecol. Appl. 15: 882-901. doi: 10.1890/040723.

Bertignac, M., Lehodey, P., and Hampton, J. 1998. A spatial population dynamics simulation model of tropical tunas using a habitat index based on environmental parameters. Fish. Oceanogr. 7: 326-334.

Beullens, K., Eding, E., Gilson, P., Ollevier, F., Komen, J., and Richter, C. 1997. Gonadal differentiation, intersexuality and sex ratios of European eel (Anguilla anguilla L.) maintained in captivity. Aquaculture 153: 135-150.

Bevacqua, D., Andrello, M., Melia, P., Vincenzi, S., De Leo, G.A., and Crivelli, A.J. 2011a. Density-dependent and inter-specific interactions affecting European eel settlement in freshwater habitats. Hydrobiologia 671: 259-265.

Bevacqua, D., Melià, P., de Leo, G.A., and Gatto, M. 2011b. Intra-specific scaling of natural mortality in fish: The paradigmatic case of the European eel. 165: 333-339.

Bonhommeau, S., Blanke, B., Tréguier, A.-M., Grima, N., Rivot, E., Vermard, Y., Greiner, E., and 
Le Pape, O. 2009. How fast can the European eel (Anguilla anguilla) larvae cross the

Brown, J.H., Gillooly, J.F., Allen, A.P., Savage, V.M., and West, G.B. 2004. Toward a metabolic theory of ecology. Ecology 85: 1771-1789.

Cairns, D.K., Secor, D.A., Morrison, W.E., and Hallett, J.A. 2009. Salinity-linked growth in anguillid eels and the paradox of temperate-zone catadromy. J. Fish Biol. 74: 2094-2114.

Clarke, A. 2003. Costs and consequences of evolutionary temperature adaptation. Trends Ecol. Evol. 18: 573-581. doi: 10.1016/j.tree.2003.08.007.

Clarke, A. 2006. Temperature and the metabolic theory of ecology. Funct. Ecol. 20: 405-412. doi: 10.1111/j.1365-2435.2006.01109.x.

Clarke, C.W. 1993. Dynamic models of behavior: An extension of life history theory. Trends Ecol. Evol. 8: 205-209. doi: 10.1016/0169-5347(93)90100-4.

Clevestam, P.D., Ogonowski, M., Sjoberg, N.B., and Wickstrom, H. 2011. Too short to spawn?

Clobert, J., Perrins, C., McCleery, R., and Gosler, A. 1988. Survival rate in the great tit Parus major in relation to sex, age, and immigration status. J. Anim. Ecol. 57: 287-306.

Colombo, G., and Grandi, G. 1996. Histological study of the development and sex differentiation of the gonad in the European eel. J Fish Biol 48: 493-512.

Côté, C.L., Castonguay, M., McWilliam, K.S., Gordon, C., and Bernatchez, L. 2014. In absence of local adaptation, plasticity and spatially varying selection rule: a view from genomic reaction norms in a panmictic species (Anguilla rostrata). BMC Genomics 15: 403. doi: $10.1186 / 1471-2164-15-403$.

Côté, C.L., Castonguay, M., Verreault, G., and Bernatchez, L. 2009. Differential effects of origin 
and salinity rearing conditions on growth of glass eels of the American eel Anguilla rostrata: and Wickström, H. 2006. Phenotypic plasticity of habitat use by three temperate eel species,

Daverat, F., and Tomás, J. 2006. Tactics and demographic attributes in the European eel Anguilla Anguilla anguilla, A. japonica and A. rostrata. Mar Ecol Prog Ser 308: 231-241.

Daverat, F., Beaulaton, L., Poole, R., Lambert, P., Wickstrom, H., Andersson, J., Aprahamian, M., implications for stocking programmes. J. Fish Biol. 74: 1934-1948. doi: 10.1111/j.10958649.2009.02291.x.

Hizem, B., Elie, P., Yalcin-Ozdilek, S., and Gumus, A. 2012. One century of eel growth: changes and implications. Ecol. Freshw. FISH 21: 325-336.

Daverat, F., Limburg, K., Thibault, I., Shiao, J.-C., Dodson, J., Caron, F., Tzeng, W.-N., Iizuka, Y., anguilla in the Gironde watershed, SW France. Mar Ecol Prog Ser 307: 247-257.

Davey, A., and Jellyman, D. 2005. Sex determination in freshwater eels and management options for manipulation of sex. Rev Fish Biol Fish 15: 37-52.

Dekker, W. 1998. Long-term trends in the glasseels immigrating at Den Oever, The Netherlands. Bull. Fr. Pêche Piscic.: 199-214. doi: 10.1051/kmae:1998045.

Dekker, W. 2000. A Procrustean assessment of the European eel stock. 57: 938-947.

Van Den Thillart, G., Palstra, A., and Van Ginneken, V. 2007. Simulated migration of European silver eel; swim capacity and cost of transport. J. Mar. Sci. Technol. 15: 1-16.

Desaunay, Y., and Guerault, D. 1997. Seasonal and long-term changes in biometrics of eel larvae: a possible relationship between recruitment variation and North Atlantic ecosystem productivity. J. Fish Biol. 51: 317-339. doi: 10.1111/j.1095-8649.1997.tb06106.x.

Desaunay, Y., Lecomte-Finiger, R., and Guérault, D. 2012. Mean age and migration patterns of Anguilla anguilla (L.) glass eels from three French estuaries (Somme, Vilaine and Adour Rivers). Arch. Pol. Fish. 20: 185-190. [accessed 22 January 2014].

Devlin, R., and Nagahama, Y. 2002. Sex determination and sex differentiation in fish: An overview of genetic, physiological, and environmental influences. Aquaculture 208: 191-364. 
596

597

598

599

600

601

602

603

604

605

606

607

608

609

610

611

612

613

614

615

616

617

618

619

620

621

Dodson, J.J., Aubin-Horth, N., Thériault, V., and Páez, D.J. 2013. The evolutionary ecology of alternative migratory tactics in salmonid fishes. Biol. Rev. 88: 602-625. doi: 10.1111/brv.12019.

Drouineau, H., Mahévas, S., Bertignac, M., and Duplisea, D. 2010. A length-structured and spatialised model for the Northern stock of European hake (Merluccius merluccius). ICES J. Mar. Sci. 67: 1697-1709.

Drouineau, H., Savard, L., Desgagnés, M., and Duplisea, D. 2012. SPAM (Sex-Structured Pandalus Assessment Model): a stock assessment model for Pandalus stocks. Can. J. Fish. Aquat. Sci. 69: $770-783$.

Edeline, E. 2007. Adaptive phenotypic plasticity of eel diadromy. Mar. Ecol.-Prog. Ser. 341: 229232.

Ernande, B., and Dieckmann, U. 2004. The evolution of phenotypic plasticity in spatially structured environments: Implications of intraspecific competition, plasticity costs and environmental characteristics. J Evol Biol 17: 613-628.

Eveson, J.P., Polacheck, T., and Laslett, G.M. 2007. Consequences of assuming an incorrect error structure in von Bertalanffy growth models: a simulation study. Can. J. Fish. Aquat. Sci. 64: 602-617. doi: 10.1139/f07-036.

Fromentin, J.-M., Myers, R.A., Bjørnstad, O.N., Stenseth, N.C., Gjøsæter, J., and Christie, H. 2001. Effects of density-dependent and stochastic processes on the regulation of cod populations. Ecology 82: 567-579. doi: 10.1890/0012-9658(2001)082[0567:EODDAS]2.0.CO;2.

Gagnaire, P.-A., Normandeau, E., Côté, C., Hansen, M.M., and Bernatchez, L. 2012. The Genetic Consequences of Spatially Varying Selection in the Panmictic American Eel (Anguilla rostrata). Genetics 190: 725-736. doi: 10.1534/genetics.111.134825.

Gardner, R., Morris, M.R., and Nelson, C.E. 1987. Conditional evolutionarily stable strategies. Anim. Behav. 35: 507-517. doi: 10.1016/S0003-3472(87)80275-0.

Geffroy, B. 2012. Déterminisme environnemental du sexe chez l'Anguille Européenne Anguilla 
anguilla. Thèse de doctorat - spécialité physiologie et biologie des organismes-populations-

Geffroy, B., and Bardonnet, A. 2012. Differential effects of behaviour, propensity to migrate and interactions, Université de Pau et des pays de l'Adour - École docorale 211 sciences exactes recruitment season on glass eels and elvers' growing performance. Ecol. Freshw. Fish 21:

Giske, J., Huse, G., and Fiksen, O. 1998. Modelling spatial dynamics of fish. Rev Fish Biol Fish 8: 469-482.

Gotthard, K., and Nylin, S. 1995. Adaptive Plasticity and Plasticity as an Adaptation: A Selective Review of Plasticity in Animal Morphology and Life History. Oikos 74: 3-17. doi: $10.2307 / 3545669$

Grimm, V., and Railsback, S. 2012. Pattern-oriented modelling: A "multi-scope” for predictive systems ecology. Philos Trans R Soc B Biol Sci 367: 298-310.

Han, Y., Hung, C., Liao, Y., and Tzeng, W. 2010. Population genetic structure of the Japanese eel Anguilla japonica: panmixia at spatial and temporal scales. Mar. Ecol. Prog. Ser. 401: 221232. doi: $10.3354 / \operatorname{meps} 08422$.

Han, Y.-S., and Tzeng, W.-N. 2006. Use of the sex ratio as a means of resource assessment for the Japanese eel Anguilla japonica: A case study in the Kaoping River, Taiwan. Zool. Stud. 45: $255-263$. river. Trans. Am. Fish. Soc. 113: 132-141.

Helfman, G., Bozeman, E., and Brothers, E. 1984. Size, age, and sex of American eels in a Georgia

(1)
et leurs applications.

Gibbs, M., Lace, L., Jones, M., and Moore, A. 2004. Intraspecific competition in the speckled wood butterfly Pararge aegeria: effect of rearing density and gender on larval life history. J Insect Sci 4: 16 . 
648 Hixon, M.A., and Jones, G.P. 2005. Competition, Predation, and Density-Dependent Mortality in Demersal Marine Fishes. Ecology 86: 2847-2859. [accessed 13 June 2014].

650 Holmgren, K. 1996. Effect of water temperature and growth variation on the sex ratio of experimentally reared eels. Ecol Freshw Fish 5: 203-212.

Holmgren, K., and Mosegaard, H. 1996. Implications of individual growth status on the future sex of the European eel. J Fish Biol 49: 910-925.

Holmgren, K., Wickström, H., and Clevestam, P. 1997. Sex-related growth of European eel, Anguilla anguilla, with focus on median silver eel age. Can J Fish Aquat. Sci 54: 27752781.

Ibbotson, A., Smith, J., Scarlett, P., and Aprhamian, M. 2002. Colonisation of freshwater habitats by the European eel Anguilla anguilla. Freshw Biol 47: 1696-1706.

Jessop, B.M. 2010. Geographic effects on American eel (Anguilla rostrata) life history characteristics and strategies. Can. J. Fish. Aquat. Sci. 67: 326-346. modèle statistique pour estimer l'échappement des anguilles argentées (Anguilla anguilla) dans un réseau hydrographique. Irstea Onema.

Kettle, A., and Haines, K. 2006. How does the European eel (Anguilla anguilla) retain its population structure during its larval migration across the North Atlantic Ocean? Can J Fish

Kettle, A.J., Asbjørn Vøllestad, L., and Wibig, J. 2011. Where once the eel and the elephant were together: decline of the European eel because of changing hydrology in southwest Europe and northwest Africa? Fish Fish. 12: 380-411.

Van Kleunen, M., and Fischer, M. 2005. Constraints on the evolution of adaptive phenotypic plasticity in plants. New Phytol 166: 49-60. 
674 Krueger, W., and Oliveira, K. 1999. Evidence for environmental sex determination in the American

675 eel, Anguilla rostrata. Env. Biol Fishes 55: 381-389.

676 Lambert, P., Verreault, G., Lévesque, B., Tremblay, V., Dutil, J.D., and Dumont, P. 2011. rostrata) aux habitats d'eau douce et établissement de priorités pour des gains en habitat. Rapport technique canadien des sciences halieutiques et aquatiques 2921.

De Leo, G.A., and Gatto, M. 1995. A size and age-structured model of the European eel (Anguilla anguilla L.). Can. J. Fish. Aquat. Sci. 52: 1351-1367.

De Leo, G., and Gatto, M. 1996. Trends in vital rates of the European eel: evidence for density dependence? Ecol. Appl. 6: 1281-1294.

Levins, R. 1963. Theory of fitness in a heterogeneous environment. II. Developmental flexibility and niche selection. Amercian Nat. 47: 75-90.

Lobón-Cerviá, J., and Iglesias, T. 2008. Long-term numerical changes and regulation in a river stock of European eel Anguilla anguilla. Freshw. Biol. 53: 1832-1844. doi: 10.1111/j.1365-

Lockwood, S.J. 1980. Density-dependent mortality in 0-group plaice (Pleuronectes platessa L.) 2427.2008.02008.x. populations. J. Cons. 39: 148-153. doi: 10.1093/icesjms/39.2.148. Fisheries Oceanography, Washington Sea Grant Program). University of Washington Press. doi: $10.2307 / 1938669$. University Press.

Mayhew, P. 2006. Discovering evolutionary ecology: bringing together ecology and evolution.

699 McCleave, J. 1993. Physical and behavioural controls on the oceanic distribution and migration of 
leptocephali. J Fish Biol 43: 243-273.

701

702

703

704

705

706

707

708

709

710

711

712

713

714

715

McLaren, I.A. 1963. Effects of Temperature on Growth of Zooplankton, and the Adaptive Value of Vertical Migration. J. Fish. Res. Board Can. 20: 685-727. doi: 10.1139/f63-046.

McNamara, J.M., and Houston, A.I. 1992. State-dependent life-history theory and its implications for optimal clutch size. Evol. Ecol. 6: 170-185. doi: 10.1007/BF02270710.

Melià, P., Bevacqua, D., Crivelli, A.J., De Leo, G.A., Panfili, J., and Gatto, M. 2006a. Age and growth of Anguilla anguilla in the Camargue lagoons. J. Fish Biol. 68: 876-890. doi: 10.1111/j.0022-1112.2006.00975.x.

Melià, P., Bevacqua, D., Crivelli, A., Panfili, J., De Leo, G., and Gatto, M. 2006b. Sex differentiation of the European eel in brackish and freshwater environments: A comparative analysis. J Fish Biol 69: 1228-1235.

Moriarty, C. 2003. The Yellow Eel. In Eel Biology. Edited by K. Aida, K. Tsukamoto, and K. Yamauchi. Springer Japan. pp. 89-105. Available from http://link.springer.com/chapter/10.1007/978-4-431-65907-5_7 [accessed 21 January 2014].

Mullen, A.J. 1989. Aggregation of fish through variable diffusivity. Fish. Bull. 87: 353-362.

Myers, R.A., and Cadigan, N.G. 1993. Density-Dependent Juvenile Mortality in Marine Demersal Fish. Can. J. Fish. Aquat. Sci. 50: 1576-1590. doi: 10.1139/f93-179.

Oliveira, K. 1999. Life history characteristics and strategies of the American eel, Anguilla rostrata. 56: $795-802$.

Oliveira, K., and Mccleave, J. 2000. Variation in population and life history traits of the American eel, Anguilla rostrata, in four rivers in Maine. Env. Biol Fishes 59: 141-151.

Oliveira, K., McCleave, J., and Wippelhauser, G. 2001. Regional variation and the effect of lake: River area on sex distribution of American eels. J Fish Biol 58: 943-952.

Pauly, D. 1980. On the interrelationships between natural mortality, growth parameters, and mean environmental-temperature in 175 fish stocks. J. Cons. 39: 175-192. 
726

728

Pigliucci, M. 2005. Evolution of phenotypic plasticity: Where are we going now? Trends Ecol Evol 20: $481-486$.

Pilling, G.M., Kirkwood, G.P., and Walker, S.G. 2002. An improved method for estimating individual growth variability in fish, and the correlation between von Bertalanffy growth parameters. Can. J. Fish. Aquat. Sci. 59: 424-432. doi: 10.1139/f02-022.

Piou, C., and Prévost, E. 2012. A demo-genetic individual-based model for Atlantic salmon populations: Model structure, parameterization and sensitivity. Ecol. Model. 231: 37-52. doi: 10.1016/j.ecolmodel.2012.01.025.

De Pontual, H., Groison, A.L., Pineiro, C., and Bertignac, M. 2006. Evidence of underestimation of European hake growth in the Bay of Biscay, and its relationship with bias in the agreed method of age estimation. ICES J. Mar. Sci. 63: 1674-1681.

Poole, W., Reynolds, J., and Moriarty, C. 1990. Observations on the silver eel migrations of the Burrishoole River system, Ireland, 1959 to 1988. Int. Rev. Gesamten Hydrobiol. 75: 807815.

Pujolar, J.M. 2013. Conclusive evidence for panmixia in the American eel. Mol. Ecol. 22: 17611762. doi: $10.1111 / \mathrm{mec} .12143$.

Railsback, S.F., and Harvey, B.C. 2013. Trait-mediated trophic interactions: is foraging theory keeping up? Trends Ecol. Evol. 28: 119-125. doi: 10.1016/j.tree.2012.08.023.

Roncarati, A., Melotti, P., Mordenti, O., and Gennari, L. 1997. Influence of stocking density of European eel (Anguilla anguilla, L.) elvers on sex differentiation and zootechnical performances. J Appl Ichthyol 13: 131-136.

Schlichting, C.D. 1986. The evolution of phenotypic plasticity in plants. Annu Rev Ecol Syst 17: $667-693$.

Schmidt, J. 1923. Breeding places and migrations of the eel. Nature 111: 51-54.

Siegfried, K.I., and Sansó, B. 2006. Two Bayesian methods for estimating parameters of the von Bertalanffy growth equation. Environ. Biol. Fishes 77: 301-308. doi: 10.1007/s10641-006- 
Sultan, S.E. 1987. Evolutionary implications of phenotypic plasticity in plants. Evol. Biol. 21: 127178.

Tesch, F.W. 2003. The Eel. Blackwell Publishing.

Travis, J. 1994. Evaluating the adaptive role of morphological plasticity. In Ecological Morphology: Integrative Organismal Biology. University of Chicago Press. pp. 99-122.

Tsukamoto, K. 1992. Discovery of the spawning area for Japanese eel. Nature 356: 789-791. doi: 10.1038/356789a0.

Tsukamoto, K., Nakai, I., and Tesch, W.-V. 1998. Do all freshwater eels migrate? [3]. Nature 396: $635-636$.

Tsurim, I., Silberbush, A., Ovadia, O., Blaustein, L., and Margalith, Y. 2013. Inter- and Intra-

Vladykov, V.D. 1966. Remarks on the American Eel (Anguilla rostrata LeSueur). Sizes of elvers Specific Density-Dependent Effects on Life History and Development Strategies of Larval Mosquitoes. PLoS ONE 8. Available from http://www.scopus.com/inward/record.url?eid=2entering streams; the relative abundance of adult males and females; and present economic importance of eels in North America. Verhandlungen Int. Ver. Für Theor. Angew. Limnol. 16: 1007-1017.

Vollestad, L.A. 1992. Geographic variation in age and length at metamorphosis of maturing European eel - Environmental effects and phenotypic plasticity. 61: 41-48.

Vollestad, L.A., and Jonsson, B. 1988. A 13-year study of population dynamics and growth of the European eel Anguilla anguilla in a Norwegian River: evidence for density-dependent mortality, and development of a model for predicting yield. J. Anim. Ecol. 57: 983-997.

Willis, J. 2011. Modelling swimming aquatic animals in hydrodynamic models. Ecol Modell 222: $3869-3887$. 
778 Table 1. Parameters values used in the four sets

\begin{tabular}{|c|c|c|c|c|}
\hline & $\begin{array}{l}\text { S0 : Control } \\
\text { experiment }\end{array}$ & $\begin{array}{l}\text { S1 : Density- } \\
\text { dependence }\end{array}$ & $\begin{array}{c}\text { S2 : Differential } \\
\text { density-dependence }\end{array}$ & $\begin{array}{l}\text { S3 : Gradient on } \\
\text { mortality }\end{array}$ \\
\hline$n$ & \multicolumn{4}{|c|}{30} \\
\hline$N_{m}(r)$ & \multicolumn{4}{|c|}{10000} \\
\hline$N_{f}(r)$ & \multicolumn{4}{|c|}{10000} \\
\hline$a_{1}$ & \multicolumn{4}{|c|}{8846 (Andrello et al. 2011) } \\
\hline$a$ & \multicolumn{4}{|c|}{1.387119 (Melià et al. 2006a; Andrello et al. 2011) } \\
\hline$b$ & \multicolumn{4}{|c|}{3.22 (Melià et al. 2006a) } \\
\hline$L_{\infty}$ & \multicolumn{4}{|c|}{$76.2 \mathrm{~cm}$ (De Leo and Gatto 1995) } \\
\hline$L s_{m}$ & \multicolumn{4}{|c|}{$40.5 \mathrm{~cm}$ (Vollestad 1992) } \\
\hline$L_{g}$ & \multicolumn{4}{|c|}{7.5 cm (Desaunay and Guerault 1997; Dekker 1998; Desaunay et al. 2012) } \\
\hline$K(r, 1)$ & \multicolumn{4}{|c|}{0.23 year $^{-1}($ De Leo and Gatto 1995) } \\
\hline$K(r, n)$ & \multicolumn{4}{|c|}{0.115 year $^{-1}$} \\
\hline$M(r, 1)$ & \multicolumn{4}{|c|}{0.138 year $^{-1}($ Dekker 2000) } \\
\hline$M(r, n)$ & \multicolumn{3}{|c|}{0.138 year $^{-1}$} & 0.103 year $^{-1}$ \\
\hline$\gamma_{M}$ & \multicolumn{4}{|c|}{0.05} \\
\hline$\gamma_{K}$ & \multicolumn{4}{|c|}{0.05} \\
\hline$\alpha_{m}$ & 0 & 0.0001 & 0.00005 & 0.0001 \\
\hline$\alpha_{f}$ & 0 & 0.0001 & 0.0001 & 0.0001 \\
\hline
\end{tabular}


782 Table 2. Consistency of the model with observed spatial patterns at the river catchment scale and at

783 the distribution area scale

\section{Patterns}

Distribution area scale

male-biased sex ratio in the southern part of the distribution area and female-biased sex-ratio in the northern part

male-biased sex-ratio in environment with high density yes

male-biased sex-ratio in fast growth environment

River catchment scale

higher density downstream than upstream

higher length-at-silvering upstream than downstream

male-biased sex-ratio downstream and female-biased sex-ratio upstream
$\begin{array}{llll}\mathrm{S} 0 & \mathrm{~S} 1 & \mathrm{~S} 2 & \mathrm{~S} 3\end{array}$

yes yes yes yes

no no yes no

no no yes no 


\section{Figures}

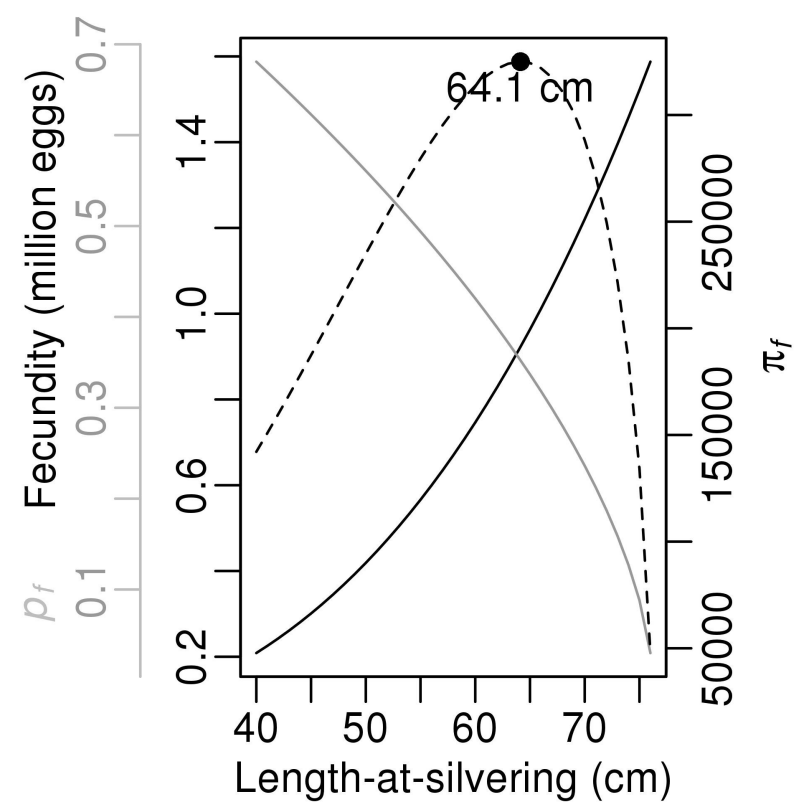

Fig. 1. Illustration of the trade-off between $p_{f}$ (grey line) and fecundity (black solid line): $p_{f}$ decreases with length-at-silvering while fecundity increases resulting in a dome-shaped mean expected reproductive output which is considered as a proxy of the fitness $\pi_{f}$ (dashed line). The optimal length-at-silvering is $64.1 \mathrm{~cm}$ for considered conditions $\left(M=0.138\right.$ year ${ }^{-1}$ (Dekker 2000) and 0.23 year $^{-1}$ (De Leo and Gatto 1995)). 


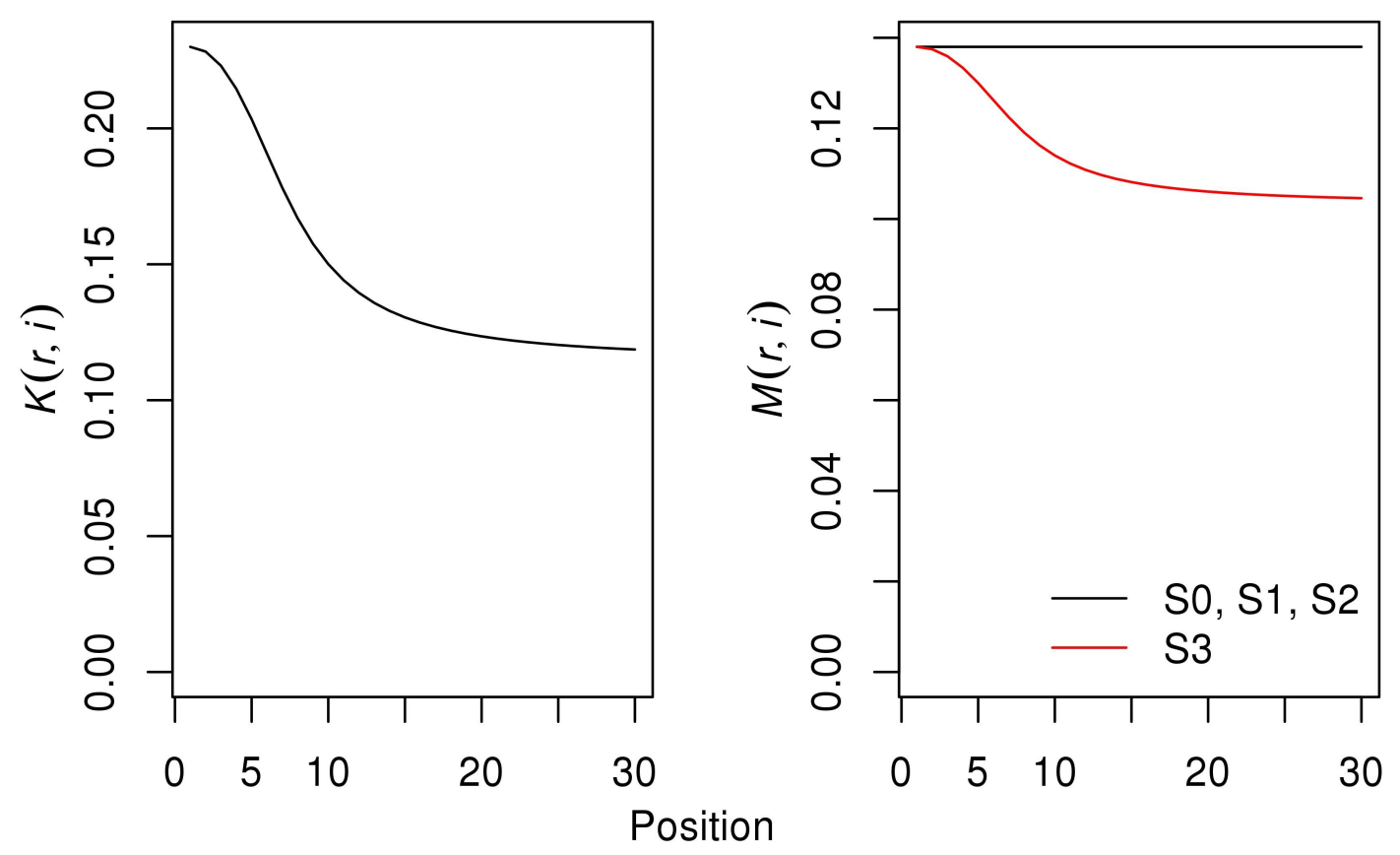

Fig. 2. Instantaneous growth rate (left panel) and instantaneous non density-dependent natural mortality (right panel) corresponding to each set of parameters. 


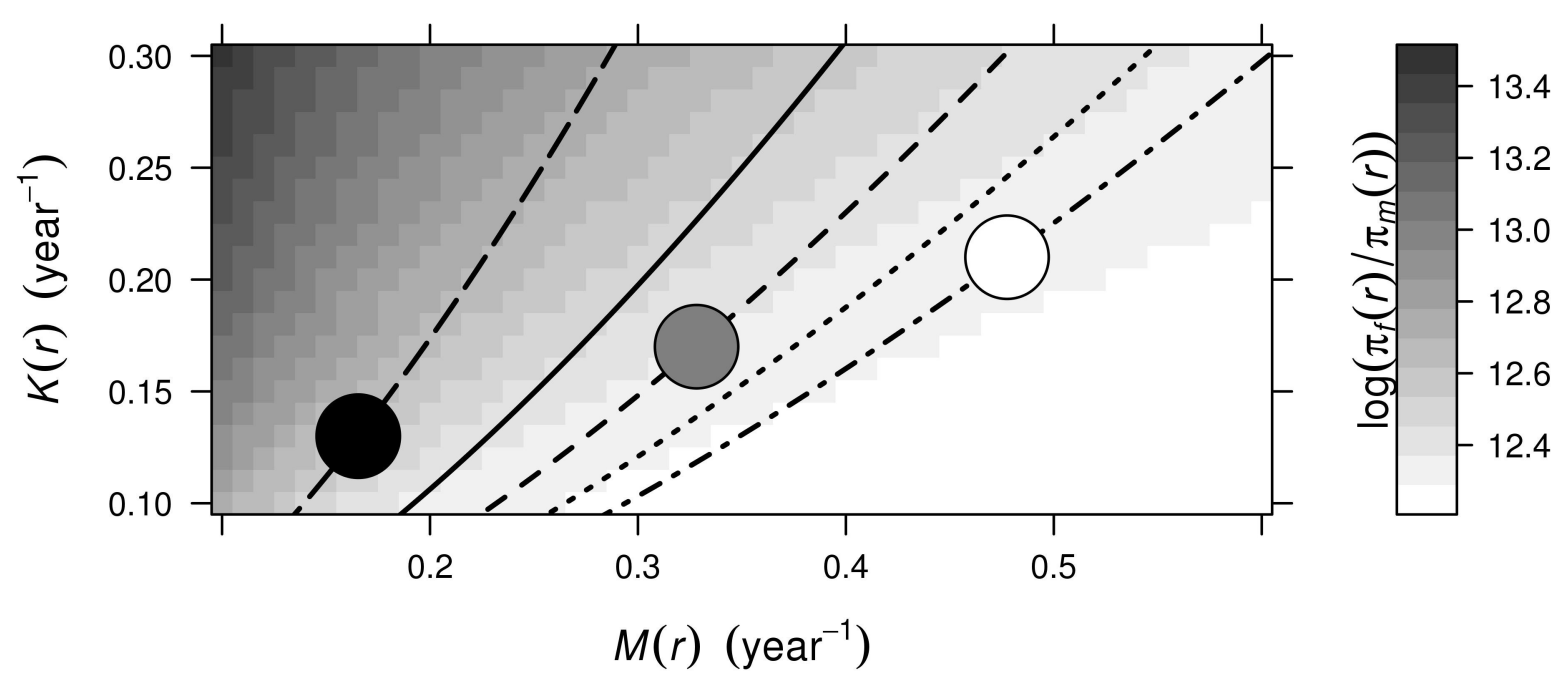

Fig. 3. Fitness ratio $\pi_{f}(r) / \pi_{m}(r)$ depending on instantaneous natural mortality rate $M(r)$ and instantaneous growth rate $K(r)$ at the catchment mouth. Dark colours indicate fitness marginal gains for females whereas light colours indicate fitness marginal gains for males. Lines represent the physiologically plausible values of $K(r)$ and $M(r)$ combinations at different temperatures based on Pauly (1980) $\left(5^{\circ} \mathrm{C}\right.$ longdash, $10^{\circ} \mathrm{C}$ solid, $15^{\circ} \mathrm{C}$ dashed, $20^{\circ} \mathrm{C}$ dotted and $25^{\circ} \mathrm{C}$ dotdash). Circles indicates putative positions for eels in Scandinavia (black circle), Bay of Biscay (grey circle) and Mediterranean lagoons (white circle) 


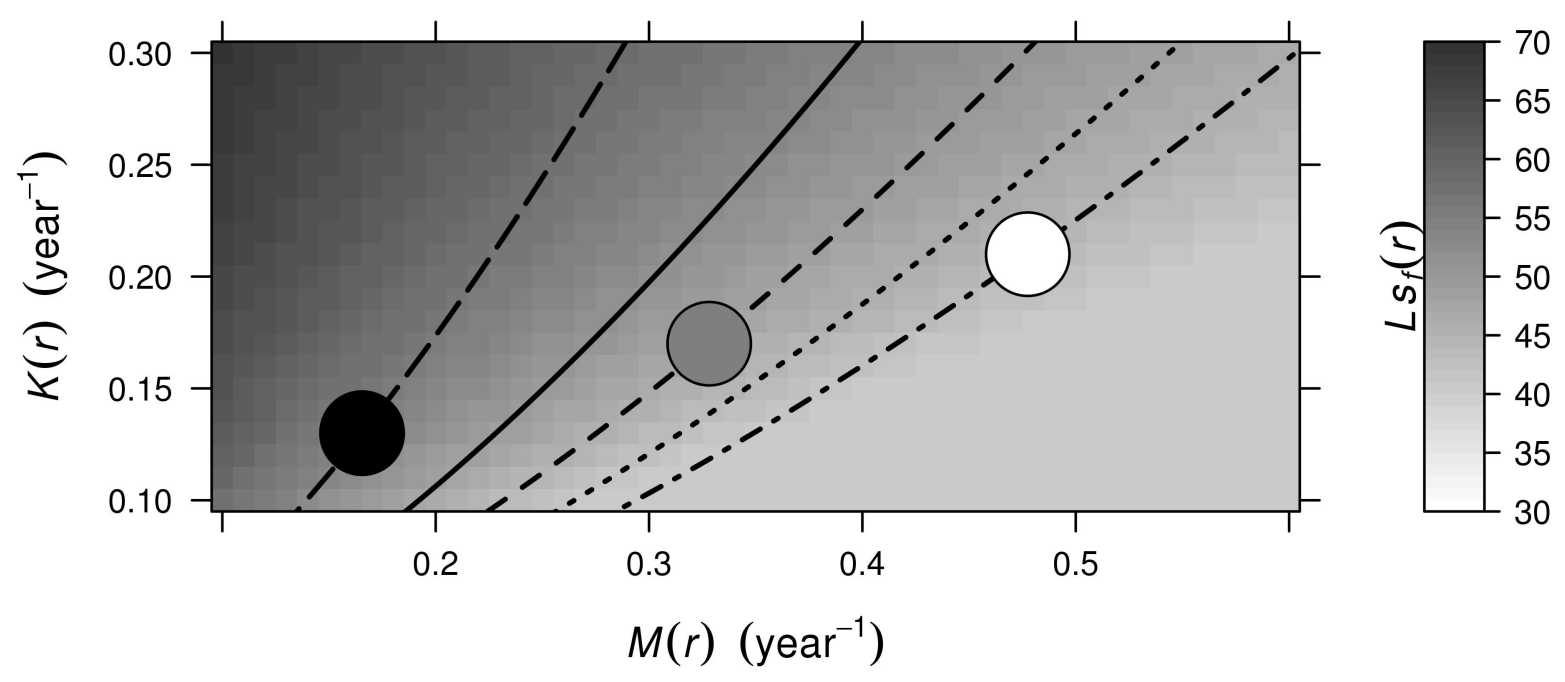

Fig. 4. $L s_{f}(r)$ maximising female fitness as a function of $K(r)$ and $M(r)$. Coloured lines represent the physiologically plausible values of $K(r)$ and $M(r)$ combinations at different temperatures based on Pauly (1980) $\left(5^{\circ} \mathrm{C}\right.$ longdash, $10^{\circ} \mathrm{C}$ solid, $15^{\circ} \mathrm{C}$ dashed, $20^{\circ} \mathrm{C}$ dotted and $25^{\circ} \mathrm{C}$ dotdash). Circles indicates putative positions for eels in Scandinavia (black circle), Bay of Biscay (grey circle) and Mediterranean lagoons (white circle). 
so

S1

S2

S3
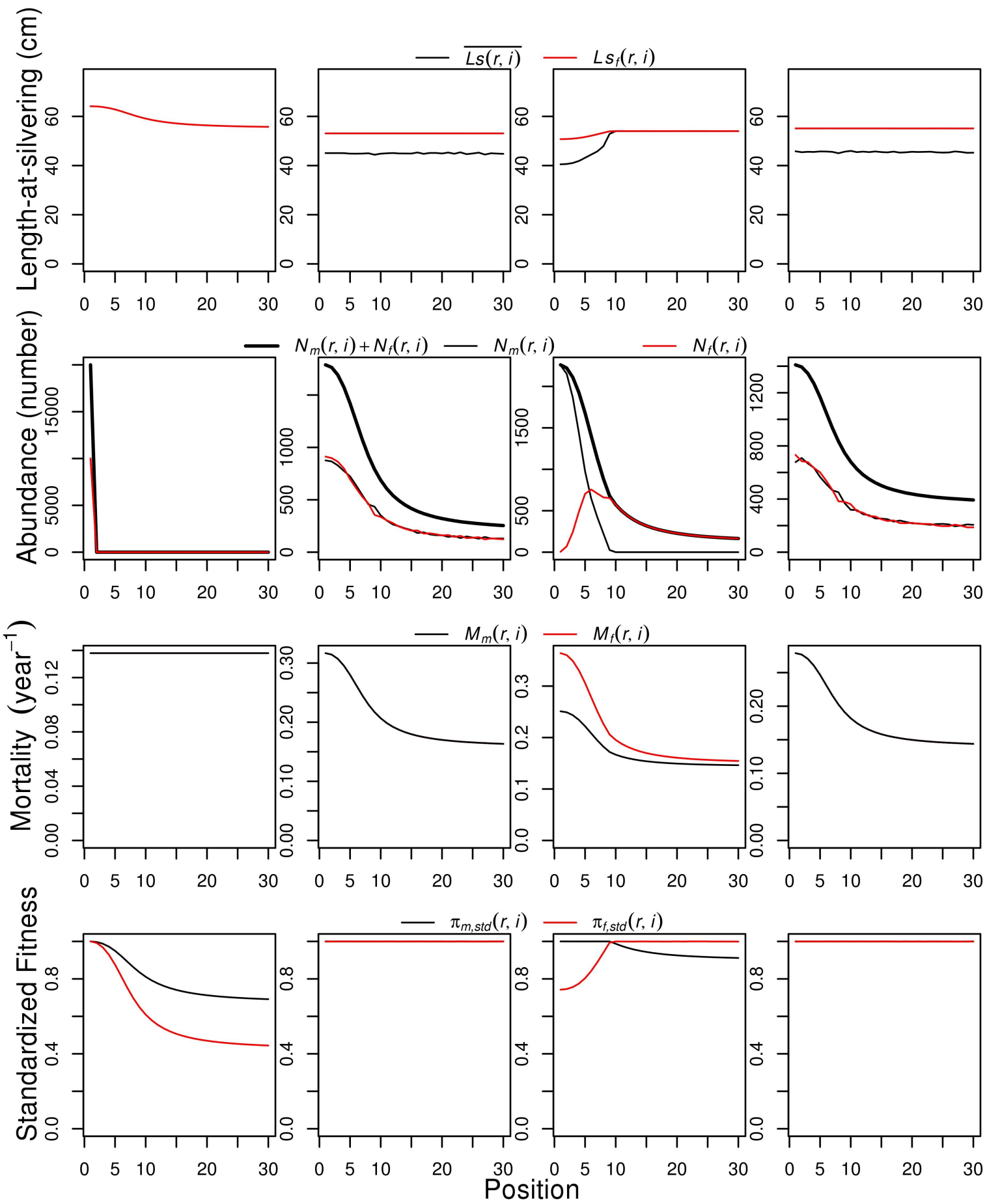

Fig. 5. Length-at-silvering, abundance, natural morality (including density-dependence), and relative fitness by sex for each set of parameters. 